\title{
Models of and approaches to the station management of six African community radio broadcasters
}

\section{Linje Manyozo, Goretti Nassanga Linda \& Claudia Lopes}

\author{
MedieKultur 2012, 52, 7-27
}

Published by SMID | Society of Media researchers In Denmark | www.smid.dk
The online version of this text can be found open access at www.mediekultur.dk

This article is a political economy critique that contributes to current scholarship on community radio and development by examining the question of the management of six networks from Mali, Mozambique and Uganda. This discussion argues that understanding the models and functions of management committees will go a long way towards contributing to conversations on how community radios could achieve social, institutional, financial and ideological sustainability. The article also examines how management committees approach their work in the age of new Information Communication Technologies (especially mobile phones, computers and the Internet), and whether there is a gender digital divide within such committees. At the centre of the current discussion, therefore, is an attempt to understand the flow and contestation of power within community radio management committees.

\section{Introduction}

This article is a political economy critique (Graham, 2005; Mansell, 2004) of the management models operative within community radio broadcasters of three African countries, namely, Mali, Mozambique and Uganda. At the centre of this discussion is the question of how ICTs have been applied by community radio management committees. 
Studies on the role of radio and development in Africa demonstrate the growing influence of rural and community broadcasters (Bosch, 2003; Fardon \& Furniss, 2000; Girard, 2003; Ilboudo, 2000, 2003; Manyozo, 2007, 2009, 2012; Nassanga, 2009a, 2009b; Teer-Tomaselli, 2001). Though these studies have attempted to show the impact of radio programming in promoting social change and development (Ansu-Kyeremeh, 1994; AFRRI \& Manyozo, 2008; Jallov, 2005; Manyozo, 2009; Moemeka, 1994), or the role of ICTs in community development (Girard, 2003; Hudson, 2006; Mansell \& When, 1998; O'Donnell, Mclver \& Rideout, 2006; Wasserman, 2011), the question of rural and community radio being shaped and reshaped by the proliferation of ICTs has not been investigated thoroughly because of lack of adequate attention to rural and community media research within the social sciences. This research seeks to address this gap in our knowledge.

To put the discussion into context, the article gives an overview of community media development in the three countries of interest: Mali, Mozambique and Uganda. The discussion analyses the importance of management committees in the functioning of the community radios and how the integration of ICTs has influenced the operations of the management committees. Based on the type of management model applied in the particular community radio and the location of the station (rural, urban/semi urban), the article focuses on four identified key roles of the radio management committees: to act as an institutional custodian of the radio station; to actively generate revenue for the station; to empower local communities to increase community capacity and community investment; and to manage the human and telecommunication resources of the station.

\section{Methodological approach}

This article is based on the findings from a larger research project, "The Implication of ICTs in the Political Economy of Community Radio Broadcasting in Africa" (Manyozo et al., 2011). Funding for the project was provided by Carleton University and the International Development Research Centre under the research initiative of "Radio and Development in Africa". The research was carried out as a cross-national survey, aiming to compare practices (of management committees, journalists and audiences) of semi-urban community radios (with better access to and use of ICTs) and those practices of rural community radios (with limited access and use of ICTs). For the purposes of this article, the discussion is based on semi-structured and open-ended interviews and focus group discussions with management committees and journalists from community broadcasters of Kagadi Kibaale and Buddu FM (Uganda); Fanaka and Welena at Nossombougou (Mali); and Gorongosa, Dondo and Gesom (Mozambique).

The interviews and focus group discussions were carried out with journalists, management committees and policy makers in Mali, Mozambique and Uganda. The survey was administered to a purposive expert sample consisting of journalists and management committees. The objectives of the interviews with the management committees and the jour- 
nalists of the seven radio stations were: (1) to establish the journalists' access to and use of ICTs; (2) to establish how ICTs are changing the political economy and media economics of rural and community broadcasting (revenue generation, financial-social-institutional sustainability); (3) to establish the perceived influence of ICTs on audience practices (listenership, participation); and (4) to establish the influence of ICTs on the practice of development radio journalism (from research to broadcasting). Management Committees were asked about their access to and use of ICTs, community participation using ICT, impact of ICTs on ownership and management of the radio stations, and community radio's contribution to the welfare of the community, as well as capacity and sustainability of the ICTs integrated.

\section{Community media development in Mali}

Ruled by a dictatorship since attaining independence from France in the 1960s, Mali experienced a political revolution in 1991, resulting in a new constitution and multiparty elections a year later. Mali is one of the poorest countries in the world (ranked 175 out of 177 countries), with French as its official language, although people speak numerous other indigenous languages. About $68 \%$ of the population lives in the rural and regional areas. Like most African countries, Mali's populations are largely illiterate and oral, traditional and indigenous forms of communications are influential and very much operative in rural knowledge societies. In societies with deep and well established traditions of orality, radio has been easily integrated as a key form of mass communication (Girard, 2003; Ilboudo, 2003; Librero, 2004). Soon after multiparty democracy became institutionalised in Mali, the Rural Radio Revival Project was launched to develop the almost non-existent rural information infrastructure and system. Logistical and financial resources for the project (which was implemented in two phases) came from Western governments and development institutions such as FAO, UNDP and UNICEF (Ilboudo, 2000; Sangaré, 2001).

After Mali became a multiparty democracy in 1992, the government implemented media reforms aimed at giving rural citizens access to various media platforms. In 1993, with funding from UNDP, the International Telecommunication Union (ITU) and UNESCO, and in collaboration with a telecommunication company, SOTELMA and the Mali Radio Broadcasting Office, the Malian government carried out an assessment of all radio and television FM frequencies, in order to promote "neighbourhood communication" throughout the country (Sangaré, 2001). The study identified more than 100 possible sites for installation of radio and television transmitters. UNICEF funded a Rural Radio Development Project executed in two phases (1993-1995; 1997-2000). Such a project became a necessity considering that the state broadcaster, Radio Mali, was an instrument for serving the minority of the population centres in the regional and rural areas (Sangaré, 2001). Today, Mali has about 250 radio stations, most of these belonging to neighbourhood or community networks. Community radios are organised under an umbrella organisation called the Malian Community Radios' Alliance. 


\section{Community media development in Mozambique}

Mozambique attained independence from Portugal in 1975, largely resulting from the pressure of the local liberation movements, especially Frelimo on one hand and the military coup in Portugal by officers, who were disgruntled with increasing expenses of fighting against liberation movements in the colonies. Immediately after independence, then President Samora Machel began a process of nationalising major institutions and industries, which resulted in major political fallout. As a result, Renamo was formed to counter what it perceived as rising communism in Mozambique. The colonial government of Zimbabwe, which was also fighting Robert Mugabe and his ZANU PF (who were being supported by the ruling Frelimo government), provided support. Later, South Africa would also sponsor Renamo, supporting the organisation's violent campaign that destroyed lives and infrastructure. This civil war ended in 1992 and multiparty elections were held in 1994.

As was the case in Mali (which also became a multiparty democracy in 1992), Western institutions and development organisations helped the Mozambican government launch a media development project. In Mozambique, the Media Project was launched after the democratisation process in 1992, with the aim of opening up the public sphere and consolidating good governance and democracy. The Media Project (undated) observes that its media development initiative involved the following major strategies: (a) strengthening the institutional capacity of the national public service broadcaster, Radio Mozambique, including its sister stations in regional areas; (b) consolidating small, independent newspapers, especially those outside urban centres, through building capacity, establishing the paper purchase scheme to allay rising printing costs; (c) establishing regional community radio stations and community multimedia centres; (d) training journalists to improve their skills and knowledge of the profession; (e) mobilising policy and law to embark on achieving gender balance in the media; and ( $f$ ) increasing the involvement of media in engaging in appropriate and effective coverage of HIV/AIDS (Media Project, undated). The development of community radio in the country involved setting up 10 radio stations and also strengthening the church-owned stations that were already operative as community broadcasters. The processes leading to the establishment of such stations involved identification of sites, mobilising and organising community groups, developing the capacity of these groups through workshops and seminars in areas of management and broadcasting, sourcing equipment, and also through providing initial running costs (Jallov, 2005).

\section{Community media development in Uganda}

Before independence, Uganda relied on traditional media as a key instrument for mass communication. After independence in 1962, there was only state-owned media, with a top-down communication approach (Nassanga, 2009a, 2009b). This trend continued until 1993 when private ownership entered the media business. This, alongside the growth of the ICT sector, shifted Uganda's media into a participatory communication model. The 
defining moment for community broadcasting though came with the emergence of Kagadi Kibaale Community Radio (KKCR) and Radio Apac in 1999, as well as Mama FM in 2000. Since then, more stations have emerged under the umbrella of community media. Nowadays, such stations pay more attention to the tastes and preferences of the surrounding communities and at the same time they work in opposition to the powerful commercial media that send commercial-packaged messages to people instead of development information. Carpentier et al. (2003) developed a four-tiered theoretical framework of community media that defines them in relation to their functional objectives. Community media are conceived as alternative, or serving a specific community, or are part of a civil society, or are rhizomatic (Carpentier et al., 2003). In the case of Uganda, such community radios started by fulfilling the first two functional objectives - of serving specific community segments, but also as citizens' media. Although these stations have been established as private stations they have participatory programming, for which communities give input to the station through calling-in or by sending SMS messages, thus providing a certain degree of participatory communication, a key characteristic of community radio.

Community media is specifically provided for in the 2004 draft broadcasting policy. As its objective, community media should be a platform for articulation of local issues; it should carry programmes in native languages, while encouraging community members to participate in the planning, production and programming (Draft Broadcasting Policy, 2004, quoted in Manyozo et al., 2011). While the policy spells out more objectives, the current research was premised mostly on the latter, which prioritises community participation. Practically, the above objectives are not all followed to the letter. For instance, Kagadi Kibaale has primetime news in English. This shows the weakness of the regulator (Broadcasting Council), for failing to enforce the policy objectives of community radio. The draft policy creates three types of responsibility accorded to the: (a) government, among others, to ensure that the relevant laws are put in place; (b) the regulator (Broadcasting Council), to "avail both geographical and interest-based community broadcasting licenses"; and to (c) the broadcaster, to "provide local content programming" (Draft Broadcasting Policy, 2004, quoted in Manyozo et al., 2011).

Another role of fostering debate by the community radios comes with numerous challenges for Uganda's very few community radios. They are, mostly, in villages where people do not have resources needed to participate in the debates, and even if they had those resources, the level of education to promote quality debate is not adequate. While Atton and Wickenden's (2005) observe that low wages and too much reliance on voluntary staff contributes to problems of sustainability of such radio networks, Manyozo et al. (2011) warn that the inadequacy of rural electrification (load shedding or no power supply) prevents the scaling out and scaling up of community media. 


\section{The question of management: Managing what?}

For both Graham (2005) and Mansell (2004), political economy of communication enables scholars to understand the flow and contestation of power within the circuit of culture, and in the case of this article, such a circuit as mediated by community radios. Our interest therefore was in examining how power manifests in the work of management committees of community radios. But what really do management committees manage? What are these management committees? And how have ICTs changed or not changed the way management committees do their work? One of the key issues emerging from the study is that though community radio scholarship (Fardon \& Furniss, 2000; Girard, 2003; Manyozo, 2011) discusses the importance of mobilising grassroots communities in setting up the relevant social infrastructure to manage the radio project before the radio is established, our research revealed that the nature and the scope of the work of the management committees is determined by two crucial factors: the model of the community radio initiative that is operative within the specific locale; and the level of democratic cultures operative within specific management committee structures (Manyozo et al., 2011; Manyozo, 2012). The question of the model is paramount as it determines the kind of linkages that the station committee has to forge in order to achieve station sustainability.

Our interviews revealed a variety of responses regarding how management committees see their work. Each of these activities or responsibilities determines the necessity of management committees using ICTs to enhance their work. What does it mean to manage a community radio? Models of Management Committees vary depending on the model of community radio operative in a particular context. We have management committees which lean towards broadcasting interests, largely because the station manager (usually one of the committee members) happens to have been influential in the establishment of the station (through linking with donor funding or training institutions), which renders the whole committee a little powerless because of their knowledge and understanding of how radio operates. There are also those management committees where the committee is much stronger and has a say in how the station is run, as a result of a strong democratic culture in the local community, something that also manifests, among other mechanisms, through regular contributions by the members of the community association.

There are also management committees that have no moral representational legitimacy (hence very dictatorial or ineffective) largely because they were either imposed by certain powerful elites or through undemocratic mechanisms. In the six case studies under investigation in our project, however, there was no evidence of national politics determining the direction of the station, even though Kagadi Kibaale recently found itself at the centre of national politics when an incumbent MP, Juliet Kabonesa, allegedly assaulted a volunteer journalist at the station Ismail Kasooha, who was suspected of taking the radio off air when the MP and her supporters were at the station for a late night paid for talk show (Mutana \& Kiva, 2011). Still there are non-democratic management committees that are professional, especially where the station leans towards private ownership - as in the case of religious 
community broadcasters. As such, in terms of power attributes, there are management committees that centralise power (for various reasons), those that are decentralised (share power with communities and are more democratic) and those that have no power at all (because they are illegitimate or outwitted and out-thought by other powerful forces such as local elite or the broadcasters).

\begin{tabular}{|l|l|l|l|}
\hline Country & Radio station & Designation & Management Committee Model \\
\hline \multirow{3}{*}{ Uganda } & Kagadi Kibaale & Rural & Democratic-centralised model \\
\cline { 2 - 4 } & Buddu FM & Semi-urban & Centralised model \\
\hline \multirow{3}{*}{ Mali } & Welena & Rural & Democratic model \\
\cline { 2 - 4 } & Fanaka & Semi-urban & Democratic-centralised model \\
\hline \multirow{2}{*}{ Mozambique } & Geosom & Rural & Democratic model \\
\cline { 2 - 4 } & Dondo & Semi-urban & Democratic model \\
\cline { 2 - 4 } & Gorongosa & Rural & Democratic model \\
\hline
\end{tabular}

Table 1: Models of community radio management (From Manyozo, Nassanga er Lopes, 2011)

In the table above, Buddu FM appears like a centralised model, largely because the station is registered as Buddu Broadcasting Services Ltd, and "incorporated as a private limited company" (Buddu FM, undated). However, the "the station positioned itself as a rural/periurban station" that works towards "addressing socio needs and problems of local communities in central Uganda for socio-economic development" (Buddu FM, undated). This corresponds with other studies (Gumucio, 2001; Manyozo, 2012; Siemering \& Fairbairn, undated), which observe that commercially-driven models of community broadcasters are increasingly appearing on the African continent. In this case, Buddu FM is a local private station that is considered a development radio because its programming is communityoriented, although its management committee is not elected by community members. In the case of Kagadi Kibaale, the station is a community broadcaster, but was established as an NGO radio - an extension and communications initiative of the indigenous development organisation the Uganda Rural Development and Training Programme.

Despite these various models, with the exception of Buddu FM, all these management committees of the radio stations spelt out similar key issues in relation to how they see and define the work of "managing a community radio". In Mozambique, the management of Radio Gesom and Radio Dondo see their role as that of providing "direccao" (direction). Within the various contexts, the question of "direccao" as a management philosophy takes on various meanings with consequential implications, ranging from overseeing, supervision, directing, and guiding to providing direction (Manyozo et al., 2011). All these real and imagined acts of management have different implications for the way ICTs are conceptualised and materialised within the station activities. For Graham (2005) and Mansell (2004), 
Article: Models of and approaches to the station management of six African ...

the management model does determine the flow of symbolic power, as it determines who speaks, where they speak, how they speak and when they speak.

\section{Role number one: To act as an institutional custodian of the radio station}

This role or responsibility is more critical for a station such as Kagadi Kibaale, which is a communications and extensions programme of a local development NGO that sees its role as a catalyst of local development in a very impoverished community. The Uganda Rural Development and Training Programme (URDT), which owns and hosts the station, was established in the late 1980s, as a "local civil society" institution that embarked upon experimenting with "self-generated" projects through the provision of relevant education and training. Central to the extension methodology of the institution is a girls' school, a vocational training programme, an African University, and principally, the Kagadi Kibaale Community Radio initiative, which started broadcasting in 2000 to, and beyond, Kibaale district. From a political economy perspective (Graham, 2005; Mansell, 2004), the management committee of the station is a site of influence where the local development organisation, URDT in this case, ensures that the organisation's participatory development ethos is reflected in the style and content of programming. Likewise in Mozambique, Gesom (Manica Social Education Group in Portuguese) was already an established NGO when the Media Project approached the project management team to start consultations on establishing a community radio (Sadique \& Jallov, 2001).

As such, the management committee, which in this case is the station management, defines what the station stands for in the local and surrounding communities, especially when the station's neutrality becomes crucially necessary, politically and ethnically. Kibaale is a district that has over 10 ethnic groups that have lived in relative harmony with each other. The challenge for the station and the radio itself has been to be a neutral arbiter when it comes to both development and political agendas, as there is a tendency by politicians, in and beyond Uganda, to mobilise popular support along ethnic lines. It is the management of the station therefore that shapes the identity of the station and the identity of its journalists. For example, when the community radio was established in Kibaale, it was necessary to highlight the development-orientedness of the station in the community. As such, it was necessary to position the community radio journalists as community development activists in their own right and exhibit passion not with their role in broadcasting, but with other local development planning and implementation activities. In fact, two journalists working for the station, Patrick Kyomuhendo and Musana Eric, emphasise that the radio station operates according to the motto of "Awakening the Sleeping Genius in Each of Us", which is itself the motto of its parent organisation, the URDT (Manyozo et al., 2011).

This specific role and responsibility have huge implications for how ICTs are integrated to define the identity of the organisation and its journalists. Firstly, an increasing number of management committee members are turning to computers, the Internet and mobile 
phones to increase the visibility of their radio stations on the net. Buddu FM, for instance, has a website (www.radiobuddu.com) and provides live streaming services, allowing a local radio station to be linked to global communities (those who share socio-economic attributes with rural Uganda). Community or development radio stations might therefore be located within specific and restrictive contexts, but their relevance transcends locality hence they are becoming glocal institutions. "Locality", which was a dividing factor that separated community and development broadcasters, has become an instrument of glocalisation. It can thus be assumed that community and development radio stations are moving towards becoming visible beyond the confines of their geographical terrains.

Importantly, community management committees that serve community radio stations, which are extension and communications arms of development NGOs, enjoy extensive support in ICT and hardware provision. The Kagadi Kibaale manager, Anthony Lwanga, has an office with assistants to help in the work. He is a key member of the management committee and who has an office and unlimited access to computer and other telecommunication services, such as a land telephone and mobile phone, and whose tariffs are subsidised by and from the station budget. Because the radio station is located within the URDT compound, the station management have direct access to each other and often interact informally (whilst being able to discuss official business). The available computer has been primarily used to print out agendas and budget outlines for discussion and processing; and even though mobile phones are employed to contact each other "once in a while", the major approach towards managerial operations is still face-to-face. However, minutes of meetings and other reports are typed and stored on the computer for easy documentation and future knowledge sharing. It is easy now, upon visiting community radio stations, to either be provided with printed copies of reports or be provided with electronic copies of the same. In Mozambique and Uganda, this has made the work of researching community radios much easier, as the management committees have improved tremendously in record keeping.

Likewise, by typing Kagadi Kibaale into a Google search, a number of links and pointers to the station come up. Some of these links come from Kagadi Kibaale itself. A couple of links can be traced to Dr. Mwalimu Musheshe, Chairperson and Chief Executive of URDT, who articulates the role and identity of the community radio station. But there are also numerous links from research carried out on the station by some journalists (such as Patrick Kyomuhendo, at www.kyomuhendobpatrick.blogspot.com, and Musana Eric, at http://www. musanaeric.blogspot.com/) or other scholars from Europe and Africa; an attempted Facebook profile, and numerous entries. It should be mentioned that because Kagadi Kibaale is perceived as a success story in community broadcasting, it has been a subject of numerous research studies in and outside Uganda, the publication and dissemination of which have increased its presence on the Internet. However, such research would not be possible without the cooperation of station management, which is always willing to provide any data and information on the history, nature and future of the station. Similarly in Mali, Radios Fanaka 
Article: Models of and approaches to the station management of six African ...

and Welena at Nossombougou also work closely with local businesses and grassroots civil society institutions.

\section{Role number two: To actively generate revenue for the station}

Considering that capital and how it is generated determine how a media institution operates in relation to internal and external competition and hostilities (Graham, 2005; Mansell, 2004), this second role remains one of the greatest challenges facing community radio stations on the African continent and beyond, largely because such radio networks are often established without coherent (social) business models in mind (Manyozo, 2012). Nevertheless, the management committees recognise their role as ensuring that the station has enough revenue to manage its operations. Initially, community management committees exist in various forms when the stations are being established. Some exist as individual community representatives during the phases of externally-driven mobilisation exercises prior to the establishment of the radio station. In more organic models of management, committees are set up prior to the initiating of the community radio network and are built upon already existing structures, such as sectorial development clubs or even radio listening clubs. In Mozambique, the Media Project of UNESCO was able to mobilise communities to establish local management committees prior to the establishment of the community radios, though there were cases where such committees were very weak and not in a position to provide direction and guidance for how the stations were to be run. The equipment that UNESCO provided to the telecentre at Radio Dondo was later taken away and redistributed to other community media projects after the centre became financially unsustainable when UNESCO pulled out. This was an indication that the station management failed to generate revenue to sustain the operational equipment. There are three principal mechanisms through which management committees define and implement revenue generation strategies.

Firstly, they identify organisations to directly provide financial support (aid) to the station or through collaborative partnerships. For most stations set up with donor funding, the very first activity of management committees especially in Mali and Mozambique was to manage the funds provided as operational costs by donor institutions. In Mozambique (UNESCO, and later, the Italian Government International Cooperation) and in Mali, the Rural Radio Revival Project (supported by UNDP, UNICEF, FAO, and ITU at different times and in different phases) provided the preliminary basic operational costs to allow for the logistical and operation take-off. In this case, management committees were required to open up bank accounts and decide on signatories to the accounts to ensure accountability. In terms of accountability, the NGO radio stations (as Kagadi Kibaale) and more private community broadcasters (as in Buddu FM) have comprehensive and institutionalised mechanisms for overseeing transparent financial expenditures.

Granted that part of the basic training provided during community mobilisation (which includes establishment of groups) does not include business and entrepreneurial develop- 
ment, managing a community radio as a media business has proven disastrous. In Mozambique, the members of the first community radio association (established under the defunct Media Project) were required to pay a joining fee of $M Z N$ 50,000 and then later a contribution of MZN 5,000 per month) (Sadique \& Jallov, 2001). As the community management associations intensify their fundraising efforts, there have been feelings expressed in local communities in the three countries, and beyond, that managing a community radio station is a "nightmare" and that it would be better to have a "community radio with an owner, which the public just listen to, without worrying about management matters" (Sadique \& Jallov, 2001).

Secondly, management committees work with the broadcasters to set prices for featuring advertisements from local businesses and the community at large. In the three countries in this study, the management committees have members who understand and have had experience fundraising. Management committees have the pedigree to strengthen the station's relationships with local businesses to ensure that the businesses in turn advertise on the radio. One unfounded and un-established consequence (which was heard in interviews with audience members) is that such business owners (often constituting part of the local elite class) exercise some control over the policies and direction of the community radio stations. So even though a community management committee may have been democratically elected by the local community, the ability to make financial contributions and payments (for advertisements and other announcements) to the stations allows local business people to exert power over a community broadcaster.

Thirdly, management committees sometimes establish short-term or long-term businesses on behalf of the station to raise funds for station operations. This involves organising suitable structures to house the radio station, liaising with relevant companies or other commercial broadcasters to repair equipment (in return for airing their programmes), or establishing business arms of the radio stations to contribute to the process of revenue generation. For Radio Gesom in Chimoio, Manica, it is very clear to the station's director, Celestino da Rocha, that for the radio to be financially sustainable, a multimedia centre has to be opened up at the back of the station's building. The multimedia centre will have between 5-10 computers (linked to the Internet) and the revenue generated would contribute to the operational costs of running this rural community radio.

Such a business move would be a reliable revenue generation mechanism considering that there are only three telecentres in the community in which many people don't have computers. Mobile phones are common and people use them to make social contacts, sending/receiving texts and making payments. When they have no money, they use SMS that is free of charge from several agents. But a huge population of young people who are interested in social media (especially Facebook and Twitter) means that there is a market for any community-based Internet service provider. Another community broadcaster, Dondo, has a long-term strategic plan for a multimedia centre, something that is also consistent with Kagadi Kibaale's strategic plan. Kagadi Kibaale station management has realised some 
small revenue from integration of ICT through computer training, Internet access, and fax/ printing services.

There is recognition, however, that the capital expenditure would outrun the capital returns, largely because it is extremely expensive to purchase computers, maintain service fees for Internet connection, technical service providers or software costs. This shows that achieving financial sustainability of ICT projects within community radio initiatives is a very financially elusive phenomenon. Although the radio stations have technicians at the station, some of the problems are beyond their capacity, since technology changes very fast and these station technicians may not have the capacity to rectify the problem. At Buddu FM, the Programme Director Pascal Mweruka explained that even though the station has a standby technician, an expatriate is brought in every two weeks to service the equipment, which they find quite expensive. Related to capacity to maintain the equipment is the environment within which these ICTs are operated. Radio Fanaka in Mali was experiencing problems due to the ICT equipment that was not very compatible with the hot weather conditions. Additionally, they were consistently dealing with the need to update antivirus software.

The challenge is that in all three countries the rural telecommunication network and infrastructure is very unreliable, largely because of the problem of economic marginalisation, in which rural and regional communities are footnoted in the national development agenda by the central governments. In Mali, in Nossombougou, the mobile phone remains the only ICT tool available to the community as a whole, and the study revealed that this mobile tool is crucial to facilitating communications and strengthening social capital as well as increasing the availability of relevant information and, more importantly, reducing distances between and within the communities themselves. There are, however, other difficulties that cannot be overlooked, especially in relation to weak signals (in rural and regional areas), poor quality of telephone sets (most of which are Chinese/East Asian brands) and the high cost of air time. Within the radio station, there have been occasions when there was congestion on the single studio line, when communities are attempting to contribute to phone-in programmes. It is recommended by the finding from this study that the questions of digital divide, let alone gender digital divide, should be framed within larger economic development debates.

\section{Role number three: To empower local communities to increase community capacity and community investment in and through the local station}

Taylor et al. (2008, p. 61) define community capacity as the self-organisation of individuals and communities in order "to get things done" - a kind of self-mobilisation that aims to improve their communities through leadership skills, social institutions, such as organisations and clubs, and social infrastructure (such as narratives, attitudes, resources and social relations). A key component of community capacity is community investment (sometimes 
referred to as active citizenship), which refers to the willingness of community members to expend energies and resources in order to improve their community. As a radio station for and by the community, community radio facilitates the increase in levels of community capacity and community investment through the activities of the community management committee. This is achieved through a number of strategies, which again have huge implications for the distribution of power at the local level (Graham, 2005; Mansell, 2004).

First, the management committee ideally comprises members of the local community who are familiar with each other and meet regularly to decide on how the station should be run. Observing the establishment of community radio associations (management committees) under the Media Project, the Director of the Radio Comunitária do Dondo highlights the importance of communities having a "stake" in the station. The emphasis on this community "stake" reflects the notion of community investment being propounded by Taylor et al. (2008) above - a factor that was a key component of the Media Project's approach towards initiating community radios as spelt out in Community Waves, a media project manual detailing the participatory approaches towards community radio establishment, which rested on thorough community consultations and collaborations (Sadique \& Jallov, 2001).

In all three countries, the community radios we studied do have community management committees of different models that are responsible for the running of the networks. By building the foundation of the community management association on local membership and strength, the station initiative attempts to achieve two forms of sustainability social and institutional. At the level of social sustainability, the community broadcasters under study reflect community involvement in the decision-making structures of the radio networks (Gumucio, 2001; Siemering \& Fairbairn, undated). Principally, all the networks are run and operated by community-based members. From political economy perspectives, questions can be raised as to the social standing of these community members. Are they educated? How many are women? Are the committees a way of strengthening social capital among the local powerful elites? What we established however is that there are fewer women (than men) participating in the activities of management committees. In Mozambique, Nhamatanda community radio, based in Sofala Province, started by the Italian Cooperation, is managed by a community-based association, which is ideally nonideological and non-political.

Another Mozambican community station, Dondo (started by the Media Project), located in a semi-urban area $30 \mathrm{~km}$ from Beira, has a community management committee that runs the network's operations. This is consistent with the "independent" community radios, such as Caia, Catandica, Búzi, Manica and others affiliated with the Institute of Social Communication (unlike the "affliated" community broadcasters owned by the Catholic Church). Similarly in Mali, Wéléna Radio of Nossombougou has 22 local members as shareholders who meet at least two times a year. For Fanaka Community Radio of Fana, the community management committee comprises seven members who meet between three to four times annually. Again, this development is consistent with other community 
Article: Models of and approaches to the station management of six African ...

broadcasters that were not under study: Nietaboulon Community Radio of Koula has a management committee that comprises 17 members, who meet three times a year; Djitoumou Community Radio of Ouelessebougou has a committee of 22 people, who meet once a year; Kafokan Public Rural Radio of Bougouni has seven management committee members meeting once annually; whilst Jamako Community Radio of Dioïla boasts a 22-member association that meets twice annually.

At the level of institutional sustainability (Gumucio, 2001; Siemering \& Fairbairn, undated), these stations draw on localness to build strong partnerships with civil society and development organisations that work in the local community. In essence, the station becomes an arbiter of development policy formulation and implementation at the local level. Radio Fanaka's management has been able to organise training opportunities for its broadcasters through establishing partnerships with the Alliance of Community Radio in Mali (ARCOM), Canadian Crossroads International (CCI) and AFRRI Mali. Fanaka Radio already has partnerships with the Malian Company for Textile Development (CMDT), the Local Chamber of Agriculture, and the City Council. Similarly, Radio Welena has partnerships with local civil society institutions in Nossombougou, the City Council and other government departments. Such partnerships prove beneficial when it comes to communicating crucial development information to local populations. For example, in Mali, Radio Fanaka has been able to promote new agricultural knowledge and technology promoted by CMDT. Likewise, when the local city council in Nossombougou translated some regulations on environmental management (including hygiene and sanitation) into local languages, the information was aired on the radio immediately, which has allowed community members to implement the suggested best practices extensively and effectively.

In 2000, the Chamber of Agriculture was able to convince the CMDT to provide favourable prices for cotton growers largely because Radio Fanaka was able to mobilise cotton growers to speak with one voice. At Kagadi Kibaale, the Mayor (of Kibaale District) William Kasaija and the Member of Parliament for the area agree that the community radio has contributed towards strengthening local information networks, especially in relation to the provision of information on government development programmes (Manyozo et al., 2011). This is very important considering that the attendance at public meetings is very poor and the radio is an intermediary between the local government authority and the grassroots. The major concern however that the local leaders point out is that the radio practices partisan politics by denying opposition parties opportunities for using the radio to make certain announcements.

An important aspect of sustainability that Gumucio (2001) and Siemering and Fairbairn (undated) do not discuss is ideological sustainability, which in the case of this study and discussion implies not only the empirical ability of any management committee to translate government policy into the operations of the radio station - but also the consistent capability to stabilise the ideological orientation of the radio station (Manyozo 2012; Manyozo et al., 2011). For political economy, policy and regulation remain sites for contesting power 
between different forces in society (Graham, 2005; Mansell, 2004). In the case of broadcasters from all six radio stations we studied, it was evident that the journalists were not very clear on what national communication policies were all about - in this case, therefore, the management committees had the responsibility of translating to the station management structures what the ideological orientation of the stations had to be. In Mali, soon after the introduction of multiparty governance in 1993, the government initiated the introduction of the national communication for development policy so as to promote an integrated and comprehensive approach towards integrating local voices and aspirations in development policy formulation and implementation. Key to this specific policy was the use of media and communications in integrating community voices and aspirations in development projects at the local level (Manyozo, 2012). The translation of such policy is the prerogative of a management committee in liaison with the station management, largely to ensure the ideological coherence of what the government proposes in legislation and what community broadcasters implement on the ground. In the same vein, the management committee acts as a broadcasting complaints commission, by arbitrating over any community concerns regarding the content of certain programmes or some broadcasters.

\section{Role number four: To manage the human and telecommunication resources of the station (in the case of the station management)}

In principle and in the literature, there is ideally a difference between a community management association/committee and station management (Manyozo, 2012; Manyozo et al., 2011). This study however established that oftentimes there were cases where the two were seemingly conflated, as in the case of Kagadi Kibaale, largely because the radio station management (which comes from the community) is already part of the management team at the URDT Programme. There were also cases, as in Mozambique and Mali, where the station manager is an influential member of the management association and undertakes unilateral management decisions, but is able to phone and co-opt a few members of the committees to ratify a specific course of action. Such a strategy not only provides a semblance of participatory decision-making, but is also logistically realistic considering the challenges of transportation especially in rural areas, which makes it impossible for association/ committee members to meet and discuss issues in person. The role of the management team in this case has been to achieve convergence, that is, to link the operations of the radio station with other components of community media and telecommunications, such as a community multimedia centre or telecentre.

The ownership and access of ICTs are implicated in these cases. Whereas the mobile phone facilitates the consultation techniques between station director and other members of the management committees (through voice calls and SMS texts, which sometimes take long to arrive), it must be pointed out that the Internet remains expensive and largely inaccessible to most members of management committees in all three countries. The Direc- 
tor of Community Radio Gorongosa in Mozambique (established in the first part of 2011) admitted making his first forays into the Internet. He has personal email and sometimes he goes to the web to exchange emails, but he does not know how to access information on the Internet. He has a mobile phone and TV at home. The station has one computer, but with no Internet access, they have one landline, and all journalists have mobile phones and use them mainly for social contacts. There are four telecentres in the village, but they are not enough to meet the information needs of this rural population and they do not provide training (one telecentre was founded by Greg Carr Project and the others are private). Journalists do not have access to the Internet. When the electronic equipment breaks down, there is a technician from the village who makes repairs, but he works on a voluntary basis, as the radio station has no money to pay to him. He also works at other radio stations (Dondo and Buzi) and receives small payments for his work.

Likewise, at Dondo Community Radio, they used to have Internet, but now they do not. They only have a Vodacom Internet card, only available to the Director, and the rest of the journalists and even the station management travel to Beira ( $30 \mathrm{~km}$ away) in order to access the Internet in the public libraries. They have 10 computers at the station, but some do not work because of viruses. They have a technician who comes to the station, but they have some problems related to hardware. Only the director has access to the Internet at work. The computer and the Internet are in her office, which makes it difficult for other journalists working in the station to access the Internet. Elsewhere, at Radio Gesom in Chimoio (the only community radio in Chimoio, Manica district), there are only two laptops, and six PCs (two are broken) at the radio station. They used to have Internet access via a landline, but the service had been stopped, because the radio station had no means to pay for it. Likewise at Fanaka Radio station, the management has ensured the provision of all ICTs, except fax and iPhones as well as BlackBerrys, to journalists. This enables journalists to use Microsoft Word to write texts. They also use other hardware such as Frontline SMS, digital recorders and MP3s to improve their programming and communication with communities. The consequence is that there exists a reciprocal implication of ICTs within and outside the station: The station's ownership of and access to ICT hardware and software shapes and is largely shaped by the ICT situation in the local area. Even though the ICT situation might be better within the radio station, it is largely shaped by the general ICT situation in the local area - and in turn the ability of the station to own and access limited ICTs in the station (especially those that promote interpersonal communication and communication between the station and the community) seems to encourage communities to access the same so as to communicate with the station.

In Mali, it was observed that ICTs (Internet, computers and mobile phones) under study have a notable impact on and within the target communities that we studied, even though the ICT indicators seem very disappointing. Around Welena Community Radio, communities of Warala, Tamani Soba and Diarrabougou, which have very limited social services and are largely agrarian economies, cell phones are very visible, but the national radio and TV 
are slightly difficult to access. Out of the 500 sampled individuals who responded to the survey questionnaires administered by Research Assistant Dramane Tounkara, 427 (85.4\%), respondents have radios, 113 (22.6\%) own television sets and 318 (63.6\%) have mobile phones (inclusive of all brands). It was even observed by one respondent that "ICTs are well integrated in the communities' way of life".

Regarding the convergence of radio and ICTs, it was observed that even simple information about stolen commodities and other related information formerly given from one person to another, or given to a griot to be spread, is now being relayed to radios by phone and then broadcast to larger audiences on a larger scale at the same time. Also, with mobile phones and rural radios, those who had to travel in order to give or pass on messages are now shifting their communication habits and practices due to ICTs. Also, national and international news are now easily delivered at the level of the communities. On the one hand, music and stories are enabling various people to avail themselves their cultural identity; on the other hand, they are enabling various individuals to express their solidarity and link one community to another. In fact, a field report from the Mali research assistant, Dramane Tounkara, observed that as much as ICTs are important towards facilitating twoway and three-way flow of information, the non-availability of power supply in rural Africa remains a huge impediment against linking rural areas to the knowledge society (Manyozo et al., 2011).

Apart from negotiating the use of ICTs within and between the station and the community, station management sees its responsibility as one of ensuring that the recruitment of volunteers and journalists reflects all forms of social diversities. At Radio Gesom in Chimoio, the Station Director observes that the station has over 65 volunteer journalists aged between 18 and 35. When they join the radio station, they enrol in a two-week course and they receive training on IT and the basics of journalism. Radio Gorongosa employs very young volunteer journalists, especially those within the 15-18 year bracket. Dondo station employs some blind journalists, and helps their integration in the community through their work on the radio. In principle, the station management (in other cases in liaison with the community management association) recruits volunteers and journalists, and organises their training. It supervises the work of journalists, ensuring they not only adhere to professional standards, but are also undertaking active strategies to involve the community in the process of creating programmes for the station. The station management also resolves conflicts especially among broadcasters and all those working within the station.

\section{Conclusion}

Framed as a political economy critique (Graham, 2005; Mansell, 2004), this discussion has identified and discussed three key issues in relation to the management of community broadcasters on the African continent. The first is the question of management itself, which has been explored in terms of giving direction (and guidance) to a specific radio 
station. Regarding this factor, the discussion indicated that the question of "direccao" as a management philosophy means overseeing, supervision, directing, guiding as well as providing direction to a community broadcaster. Such "direccao" is practiced in three different models of management: the democratic-centralised, centralised and democratic models of station management. The second is that community radio management committees see their work as encompassing four major responsibilities: acting as institutional custodians of the radio stations; generating revenue for the station; institutionalising increased community participation in the radio activities; and managing the human and telecommunication resources of the station (Manyozo, 2012).

The third issue investigated in the article relates to the question of convergence of ICTs and community radios. The article has argued that the extant lack of coherent and comprehensive financial sustainability mechanisms threaten the survival of community radio stations (especially those that are relatively independent and do not operate under any development organisation) as well as the integration of ICTs (such as computers, Internet and mobile phones). To discuss the convergence of community radio and ICTs therefore requires a comprehensive and honest conversation about the relevant business models that are going to financially sustain their use within the stations. There is no point buying a new computer for a station that will not have enough money to hire someone to repair it when it has broken down. There is no point connecting this computer to the Internet when three months down the line the connection is going to be cut off for non-payment of bills.

Importantly, the study did not find any clear evidence to suggest that ICT availability has impacted the way management committees work. What we learned was that individual members of these committees have made the conscious effort to use mobile phones, computers or the Internet, but this has not impacted much in the way they work. Except in circumstances where commercially-driven Buddu FM is able to provide live broadcasts on the Internet and increase its visibility in the public domain (hence its marketability and, consequentially, its commodification), or in the case of Kagadi Kibaale (where the URDT provides some ICT services to the management committees), it is very obvious that ICTs are not contributing much to the digital inclusion debate at the management level. In this qualitative study therefore, it would not make logical sense to conclude that there is a gender digital divide within the radio-ICT convergence, because at the managerial level, there is no such convergence yet. What exists is sporadic interaction between ICTs and individual members of management committees or associations. 
Article: Models of and approaches to the station management of six African ...

\section{References}

Ansu-Kyeremeh, K. (1994). Communication, Education and Development: Exploring an African Cultural Setting. Alberta: EISA Publishers.

African Farm and Rural Radio Initiative and Manyozo, L (2008). Communicating with radio: What do we know? Findings from selected rural radio effectiveness evaluations. Ottawa: Farm Radio International. Retrieved September 11, 2011 from: http://www.farmradio.org/english/partners/afrri/communicating-with-radio.pdf

Atton, C. and Wickenden, E. (2005). Sourcing routines and representation in alternative journalism: A case study approach, Journalism Studies, 6(3): 347-359.

Bosch, T. (2003). Radio, community and identity in South Africa: A rhizomatic study of Bush Radio in Cape Town. Unpublished PhD Thesis. College of Communication, Ohio University, Ohio, USA.

Burger, G. (2005). Doing digital journalism: How Southern African news-gatherers are using ICT. Research report. Rhodes: Highway Africa, Rhodes University. Retrieved September 11, 2011 from: http://www. highwayafrica.com/media/guyberger/Doing_Digital_Web.pdf

Carpentier, N., Lie, R. and Servaes, J. (2003). Community media: muting the democratic media discourse? Continuum: Journal of Media and Cultural Studies, 17(1): 51-68.

Dralega, A.C. (2009). Participatory ethos, multimedia experiments and disjunctures in community media in Uganda. Ecquid Novi: African Journalism Studies, 30(1): 24-41.

Fardon, R. and Furniss, G. (eds.) (2000). African Broadcast Cultures: Radio in Transition. Oxford, Harare, Cape Town and Westport: James Currey, Baobab, David Philip and Praeger.

Girard, B. (ed.) (2003). The One to Watch: Radio, New ICTs and Interactivity. Rome: FAO and Friedrich Ebert Foundation.

Graham, P. (2005). Political economy of communication: A critique. Canada Research Chair in Communication and Technology, University of Waterloo. Available at: http://www.philgraham.net/MME\%20 Chapter_Final.pdf

Gumucio, A. (2001). Making Waves: Stories of Participatory Communication for Social Change. New York: Rockefeller Foundation.

Hudson, H.E. (2006). From Rural Village to Global Village: Telecommunications for Development in the Information Age. New Jersey: Lawrence Erlbaum Associates.

Ilboudo, J. (2000). Prospects for rural radio in Africa: prospects to relate audience research to the participatory production of radio programmes. In R. Fardon \& G. Furniss (ed.), African Broadcast Cultures: Radio in Transition (pp.42-71). Oxford, Harare, Cape Town and Westport: James Currey, Baobab, David Philip and Praeger.

Ilboudo, J. 2003. After 50 years: The role and use of rural radio in Africa in Africa. In Girard, G. (ed.), The one to watch: radio, new ICTs and interactivity (pp. 209-220). Rome: FAO and Friedrich Ebert Stiftung.

Jallov, B. (2005). Assessing community change: Development of a 'barefoot' impact assessment methodology. The Radio Journal: International Studies in Broadcast and Audio Media, 3(1): 21-34.

Librero, F. (2004). Community Broadcasting: Concept and Practice in the Philippines. Singapore: Marshal Cavendish International.

Mansell, R.E. and Wehn, U. (1998). Knowledge Societies: Information Technology for Sustainable Development. Oxford: Published for the United Nations Commission on Science and Technology for Development by Oxford University Press.

Mansell, R.E. (2004). Political economy, power and new media. New Media and Society, 6(1): 96-105.

Manyozo, L. (2007). Local rural radio as a development radio: Dzimwe community radio in Malawi. Global Journal of Communication for Development and Social Change, 2(2): 167-192. 
Article: Models of and approaches to the station management of six African ...

Manyozo, L. (2009). Mobilizing rural and community radio in Africa. Ecquid Novi: African Journal of Journalism Research, 30(1): 1-23.

Manyozo, L. (2012). People's Radio: Communicating Change Across Africa: Penang: Southbound.

Manyozo, L., Nassanga, G. and Lopes, C. (2011). The Implication of ICTs in the Political Economy of Community Radio Broadcasting in Africa: A Comparative Investigation into the Listenership to, Content Production for and Management of Community Radio Broadcasters in Mali, Mozambique and Uganda. Research Report submitted to Carleton University (Unpublished). London and Ottawa: London School of Economics and Carleton University.

Megwa, E.R. (2007). Community radio stations as community technology centres: An evaluation of the development impact of technological hybridization on stakeholder communities in South Africa. Journal of Radio Studies, 14(1): 49-66.

Moemeka, A. (1994). Radio strategies for community development: A critical analysis. In Communicating for Development: A New Pan-disciplinary Perspective (pp. 124-140). Albany: State University of New York.

Mutana, M and Kiva, F (2011). Journalist accuses Kibaale woman MP of Assault. Retrieved September 11, 2011 from: http://ugandaradionetwork.com/a/story.php?s=31497

Nassanga, G.L. (2009a). An assessment of the changing community media parameters in East Africa. Ecquid Novi: African Journalism Studies, 30(1): 42-57.

Nassanga, G.L. (2009b). Participatory discussion programs as 'hybrid community media' in Uganda International Journal of Media and Cultural Politics, 5(1): 119-124.

Obera, F. (2007) Community radios empower development in Kenya. Imc-africa Community Radio in Kenya. Retrieved September 11, 2011 from: http://lists.indymedia.org/pipermail/imc-africa/attachments/20061017

O'Donnell, S., Mclver, W., \& Rideout, V. (2006) Community media and networking and ICT. Paper presented at the Canadian Communication Association Annual Conference, York University, Toronto, 2006. Retrieved September 11, 2011 from: http://iit-iti.nrc-cnrc.gc.ca/iit-publications-iti/docs/NRC-48743.pdf

Sadique, F. and Jallov, B. (2001). Community Waves: Some Experiences in Supporting the Establishment of Community Radios by UNESCO in Mozambique. Maputo: UNESCO and the Media Project, unpublished. Retrieved September 11, 2011 from: http://www.mediamoz.com/CR/CR_WAVES.pdf

Sangaré, O. (2001). Impact of radio broadcasts in the Mali-south region: Follow-up and evaluation. Paper presented at the International Workshop on Farm Radio Broadcasting: Information and Communication Technologies (ICTs) Servicing Farm Radio: New Contents, New Partnerships, 19-22 February 2001, Rome, Italy. Retrieved September 11, 2011 from: http://www.fao.org/documents/show_cdr.asp?url_ file $=/$ docrep $/ 003 / \times 6721$ e $/ \times 6721 e 28 . h t m$

Siemering, B. and Fairbairn, J. (undated). Developing radio partners: Guidebook on sustainability. Retrieved September 11, 2011 from: http://www.docstoc.com/docs/146118/Guidebook-on-sustainability

Taylor, J., Wilkinson, D. and Cheers, B. (2008). Working with Communities in Health and Human Services. Oxford: Oxford University Press.

Teer-Tomaselli, R. (2001). Who is the 'community' in community radio? A case study of community radio stations in Durban, KwaZulu Natal. In K. Tomaselli and H. Dunn (eds.), Media, democracy and renewal in Southern Africa: New approaches to political economy (pp. 231-254). Colorado Springs, CO: International Academic Publishers.

The Media Project (undated) The Media Project: Strengthening democracy and governance through development of the media in Mozambique. Retrieved September 11, 2011 from: http://www.mediamoz.com/

Wasserman, H. (2011). Mobile phones, popular media, and everyday African democracy: Transmissions and transgressions. Popular Communication, 9(2): 146-158. 
Article: Models of and approaches to the station management of six African ...

Linje Manyozo

PhD, Lecturer and Programme Director Department of Media and Communications London School of Economics and Political Science, United Kingdom kucheza@gmail.com

Goretti Nassanga Linda PhD, Associate Professor Journalism \& Communication Department Makerere University Kampala, Uganda nassanga@masscom.mak.ac.ug Claudia Lopes PhD, Teaching Fellow Department of Social Psychology London School of Economics and Political Science, United Kingdom cabreulopes@gmail.com 